УДК 793.32

Крись Андрій Іванович викладач кафедри сучасної та бальної хореографії, Киїський національний університет культури і мистецтв, Київ, Украӥна

Krys.rumba@gmail.com

\title{
КОМПОЗИЦІЙНІ ОСОБЛИВОСТІ ХОРЕОГРАФІЧНОГО ЕТЮДУ
}

Мета дослідження. Розглянути та проаналізувати композиційні особливості хореографічного етюду, а також дослідити тенденції становлення принципів хореографічної композиційної побудови та драматургії постановок. Методологію дослідження становить органічна сукупність базових принципів дослідження: об'єктивності, історизму, багатофакторності, системності, комплексності, а для досягнення мети дослідження використані наступні методи наукового пізнання: проблемно-хронологічний, конкретно-історичний, статистичний, описовий, логікоаналітичний. Наукова новизна статті полягає в комплексному аналізі композиційних особливостей хореографічного етюду та висвітленні головних принципів композиційної побудови та драматургії постановок. Висновки. 3'ясовано, що своєрідність створення хореографічного етюду як невеликого за обсягом, але багатокомпонентного самостійного завершеного сюжетного твору полягає в урахуванні таких компонентів як оранаментальність танцю, що наділяє хореографічну композицію змістовністю та декоративністю, композиція танцю, яка складається зі змісту (драматургії), відповідного музичного супроводу, хореографічного тексту і малюнка, ракурсів, проте найголовнішим та пріоритетним лишається творча особистість хореографа, його темперамент, уява, образне мислення, цілісність переконань при визначенні надзавдання, сміливість експериментувати задля втілення неординарних, новаторських хореографічних постановок.

Ключові слова: хореографічний етюд, композиція, музично-хореографічний сценарій, хореограф-постановник.

Крысь Андрей Иванович преподаватель кафедры современной и бальной хореографии, Киевский начиональный университет культуры и искусств, Киев, Украина

Композиционные особенности хореографического этюда 
Цель исследования. Рассмотреть и проанализировать композиционные особенности хореографического этюда, а также исследовать тенденции становления принципов хореографического композиционного построения и драматургии постановок. Методологию исследования составляет органическая совокупность базовых принципов исследования: объективности, историзма, многофакторности, системности, комплексности, развития и плюрализма, а для достижения цели исследования использованы следующие методы научного познания: проблемно-хронологический, конкретно-исторический, статистический, списательный, логико-аналитический. Научная новизна статьи состоит в комплексном анализе композиционных особенностей хореографического этюда и освещении главных принципов композиционного построения и драматургии постановок. Выводы. Выяснено, что своеобразие создания хореографического этюда как небольшого по объему, но многокомпонентного самостоятельного завершенного сюжетного произведения заключается в учете таких компонентов как оранаментальность танца, что придает хореографической композиции содержательности и декоративности, композиция танца состоит из содержания (драматургии), соответствующего музыкального сопровождения, хореографического текста и рисунка, ракурсов, однако самым главным и приоритетным остается творческая личность хореографа, его темперамент, воображение, образное мышление, целостность убеждений при определении сверхзадачи, смелость експериментировать ради воплощения неординарных, новаторских хореографических постановок.

Ключевые слова: хореографический этюд, композиция, музыкальнохореографический сценарий, хореограф-постановщик.

Krys Andrii lecturer of Modern and Ballroom Choreography, Kyiv National University of Culture and Arts, Kyiv, Ukraine

\section{Compositional features of a choreographic sketch}

The purpose of the article is to study and analyze the compositional features of a choreographic sketch; to examine the trends of formation of the principles of choreographic composition and production dramaturgy. The research methodology consisted in the organic combination of the basic principles of research: objectivity, historicism, multifactorness, consistency, comprehensiveness; to achieve the objectives of the research, the following methods of scientific knowledge were used: problemchronological, concrete-historical, statistical, descriptive, logical and analytical. The scientific novelty of the work lies in the comprehensive analysis of the compositional features of a choreographic sketch and highlighting the main principles of composition and production dramaturgy. Conclusions. It was found that the uniqueness of creating a choreographic sketch as a small but complex independent 
story lies in the consideration of such components as ornamentality of dance, which makes the production meaningful and decorative; dance composition, which consists of dramaturgy, background music, choreographic patterns and angles. However, the top priority is the creative personality of the choreographer, their temperament, imagination, creative thinking, integrity of beliefs in setting the super-task, their courage to experiment for the sake of realizing extraordinary and innovative choreographic productions.

Key words: choreographic sketch, composition, music and dance scenario, choreographer.

Вступ. Стан і тенденції сучасного хореографічного мистецтва в Україні в контексті діяльності хореографів-постановників наразі є однією з важливих тем, які привертають увагу дослідників, адже в процесі історичного розвитку та становлення являє синтез найвизначніших набутків не лише української, а й світової хореографії. Актуальним для наукового дослідження стає виявлення принципів композиційної побудови та особливостей драматургії хореографічних постановок загалом та хореографічного етюду зокрема, задля використання в процесі професійної освіти та творчої діяльності у галузі хореографічного мистецтва.

Мета статті полягає в аналізі композиційних особливостей хореографічного етюду, а також дослідженні тенденцій становлення принципів хореографічної композиційної побудови та драматургії постановок.

Аналіз досліджень. Дослідженню особливостей хореографічного мистецтва в контексті композиційних та драматургічних особливостей присвячені роботи Л. Блок, Р. Захарова, В. Ванслова, В. Волькенштейна, І. Вороніна, М. Івановського, О. Касьянової, М. В. Васильєвої-Рождєствєнської, Ю. Станішевського та ін. Проте, висвітлюючи актуальні питання теорії хореографічного мистецтва, проблеми драматургії, сценічної форми постановок та архітектоніку великих хореографічних форм, питання виявлення принципів композиційної побудови та особливостей драматургії хореографічного етюду в контексті використання в процесі професійної освіти та творчої діяльності у галузі хореографічного мистецтва лишаються не достаньо висвітленими, що й зумовлює актуальність даного дослідження.

Виклад основного матеріалу. Хореографічний етюд, невеликий за обсягом твір композиційно закінченої форми, включає лексику та композиційний малюнок і виконується не в якості демонстрації технічної майстерності виконавців, а задля передачі змісту авторської теми. За композиційними формами етюд може бути представлений як соло (solo), дует, (douette), тріо (trio), квартет (quartette) або масовий. 
Велике значення в процесі підготовки хореографа мають етюди на композиційний малюнок, оскільки композиція (лат. compositio - складання, поєднання, створення, побудова) - найважливіший компонент художньої форми, що надає твору цілісності та єдності, а структура твору, зумовлена змістом, відображає об’єктивну взаємодію подій [1, с. 24]. Варто зазначити, що іноді термін «композиція» у хореографії означає короткий елемент танцю або його просторове рішення (малюнок, фігури). У даному випадку, етюди на композиційний малюнок передбачають визначення хореографічної композиції як власного твору хореографа, співставлення різноманітних танцювально-пластичних елементів (кроків, рухів) та розташування їх у просторі майданчику або сцени.

Композиційний малюнок - розташування і переміщення танцівників на сценічному майданчику, відповідає ідеї твору та емоційному стану героїв, проявляючись в їхніх вчинках. Він має повною мірою виражати головну думку, характер та настрій закладені в танцювальному номері. Працюючи над композиційним малюнком варто пам'ятати, що велике значення при створенні образу мають хореографічний текст (опис комбінацій, рухів, жестів, поз, ракурсів, міміки) та засоби сценічної виразності - костюм, музичний супровід, освітлення тощо; логіка його розвитку передбачає зв'язок попереднього малюнку 3 наступним, при цьому кожен наступний малюнок має бути розвитком попереднього.

Як синтетичний твір, адже хореографія не існує за межами синтезу мистецтв, хореографічний етюд складається з таких компонентів як сценарій, музичний супровід та власне хореографія, яка відіграє превалюючу роль, а їх органічне поєднання надає постановці художньої сили та виразності. Відтак, центром етюду є танцювально-пластичний вираз життєвого змісту, що тримається на драматургії - конфліктному розвитку подій, завдяки якому відображається життєве протиріччя.

В. Волькенштейн, аналізуючи музично-хореографічну драматургію танцю, наголошував, що танець слід сприймати як драму, написану музикою, що ніби вбирає ii в себе і отримує дійове значення, створюючи основу - музичну драматургію, здійснену засобами хореографії - образно-танцювальним втіленням [2, с. 143].

Постановник етюду в даному випадку виступає в якості автора сценарію, режисера та хореографа, а кожна хореографічна композиція будується відповідно до законів драматургії та складається з певних танцювальних комбінацій на конкретному музичному матеріалі.

Діяльність відомих балетмейстерів-новаторів XVII-XVIII ст. відіграла неабияке значення на формування принципів хореографічної композиційної побудови та драматургію постановок. Так, наприклад, англійський хореограф 
Д. Уівер (1673-1760) вперше запропонував відмовитись від вербаліки і дозволити танцю самостійно виражати думки за допомогою унікальної лексики. Саме йому належить відомий вислів про балет: «Варто знати, що яким би безглуздим не було це мистецтво, хороший танцівник не може не володіти розумом» [3, с. 15]. Відомий теоретик танцю, якому належати книги та статті «Короткий курс 3 танцювального темпу і ритму», «Збірка придворних бальних танців», «Досвід про історію танцю», «Бесіди про анатомію та механіку танцю», «Історія мімів і пантомім», пропонував навчитися у давнього танцю виражати психічний стан жестами та рухами тіла. Д. Уівер виклав власну класифікацію танців та систему сценічних рухів, розуміння гармонії сюжету і пластики, сприяв розвитку хореографічної драматургії, пропагуючи переконання про ऑiі єдність зі сценарної. Варто зазначити, що саме його праці відіграли неабияке значення на світогляд та творчість Ж.-Ж. Новерра.

Австрійський балетмейстер Ф. Хільфердінг (1710-1768) вважав, що вершиною вільних мистецтв є наслідування «простій і прекрасній природі, яке має зливатися з вдалою вигадкою» [3, 28]. Відповідно до його розуміння, найголовнішою реформою мало б стати реорганізація балету в самостійний театральний жанр, головна увага в якому зосереджувалась на драматургії хореографічної постановки. Сприяючи оновленню танцювальної техніки та відмові від масок, Ф. Хільферлінг сприяв появі дієвого танцю, створюючи нові образи героїв у міфологічних балетних постановках «Орфей і Евридіка», «Пігмаліон», «Уліс та Цирцея» (1740-1750-ті рр.) він передбачив появу танцю-поеми.

Його учень та послідовник Г. Анджоліні (1731-1802 рр.) вважав музику основою та поетичною душею хореографічної вистави, а музичну драматургію основою сценічної дії.

Англійський актор театру пантоміми Д. Річ (1691-1761 рр.), який доповнював свої вистави хореографічними етюдами, пов’язував танці 3 сюжетом пантомімної дії і підбирав музику, яка відповідала дії вистави.

Ж.-Ж. Новерр (1727-1810 рр.), прагнучи до ствердження власної естетики балетного мистецтва, у теоретичній праці «Листи про танець і балет» [4] поновому осмислював хореографічну драматургію, розробки сюжету постановок та акцентував на доцільності поєднання музики, в якій закладена драматургія та хореографії.

Італійський балетмейстер С. Вігано (1769-1821 рр.), поділяючи погляди своїх попередників, створював сюжети балетів на основі літературних творів, звертався до надскладних тем і образів («Любов до трьох апельсинів» за Гоцци, «Гамлет», «Отелло», «Макбет» за У. Шекспіром). На його думку канонізовані форми танцю порушували єдність вистави, а тому прагнув змінити засоби художньої виразності. С. Вігано створив ритмізовану пантоміму, залучив до хореографічної партитури національні танці, задля підсилення колориту постановки. 
Актуальним при створенні хореографічного етюду, як і будь-якої постановки, є розуміння важливості хореографічного сценарію, драматургії, розкриття художнього образу, думок та почуттів героїв засобами хореографічної виразності.

Головні принципи композиції у хореографії:

- пролог - перша частина хореографічного твору, якою починається дійство; у хореографічній мініатюрі та етюді допускається відсутність прологу;

- експозиція - початок основної дії;

- зав'язка - частина, з якої починається конфлікт та головна інтрига відповідно до задуму постановника;

- розвиток дії - зростання конфлікту та репрезентація дії відповідно до задуму постановника;

- кульмінація - частина, в якій інтрига та конфлікт максимально зростають, внаслідок чого в розвитку відбувається злам;

- спад дії - зменшення напруги, згасання конфлікту;

- розв'язка - конфлікт добігає кінця, розкривається головна інтрига;

- фінал - закінчення хореографічної постановки, що характеризується логічним висновком репрезентованих за сюжетом подій;

- епілог - своєрідне резюме постановника; події, що відбуваються через відповідний проміжок часу після фіналу.

Основні складові хореографічного етюду : експозиція, зав’язка, розвиток дії, кульмінація та розв'язка.

Аналізуючи процес створення танцю, Р. Захаров наголошує, що в його основі лежить задум постановки, виникнення і зміст якого залежать від таких факторів як життєвий досвід, талант, інтелект, внутрішня культура хореографа тощо. Мислячи хореографічними образами, уявляючи майбутній етюд, зовнішній вигляд танцівників, образне вираження відносин між ними і утвердившись у власному баченні, постановник має обрати життєвий матеріал, як основу хореографічного образу майбутнього етюду, дослідити та проаналізувати етнографію та історію обраної теми, визначитися з формою та жанром танцю, які мають відповідати задуму і сприяти ідейній виразності. Наголосимо на доцільності збереження авторського стилю та своєрідної індивідуальної атмосфери, за умов, що сценарій етюду створюється за мотивами певного твору [5, c. 134$]$.

Невід’ємною частиною роботи над постановкою етюду є створення композиційного плану - розгорнутого музично-хореографічного сценарію постановки, номеру або балету, що базується на режисерсько-балетмейстерській розробці сюжету і розкриває сценічне рішення теми (те, про що йдеться в даному хореографічному творі) та ідеї (найголовнішої думки чи почуття автора щодо певної події, яка відображена і втілюється в конфліктах, характерах, 
композиції, ритмі та динаміці) твору, образи дійових осіб, музичний супровід. Варто наголосить, на важливості підходу постановника при визначенні музичного оформлення етюду, декорацій чи інвентаря (при необхід-ності), костюмів та сценічного освітлення, адже вони сприяють підсиленню атмосфери, змісту, характеру твору, художній виразності та створенню єдиного зорово-музичного образу.

Заключний етап постановки етюду передбачає безпосереднє вивчення рухів, елементів та комбінацій, які хореограф має відкорегувати відповідно до фізичних можливостей танцівників та доопрацювати виразність хореограффічного тексту.

В. Нікітін [6, с. 30-31] при створенні хореографічної композиції рекомендував акцентувати увагу на:

- мотиви - основу твору; визначити рухи, сценографію та світлове оформлення, лінії та форми простору, образи та логіку манери поведінки виконавця, при умові залучення кількох повторів побудованих на контрастах або варіаціях та кульмінації, яка сприяє наповненню мотиву змістом, передає ідею постановника, логічних переходів, що сприяють поєднанню мотивів у єдиний хореографічний текст та логічного розвитку від одного мотиву до іншого;

- повторення - збільшення кількості рухів або навпаки, акцентування на них за допомогою пауз; використання засобу «відлуння», тобто використання окремої частини матеріалу у новому контексті; засобу «резюме» - повторення основної частини мотиву в збільшеному або зменшеному варіанті; засобу «огляд» - повторенні певних частин мотиву кілька разів; засобу «запам'ятовування» - у новому змісті використовуються окремі відголоски (змінені але 3 помітним асоціативним зв’язком 3 використаним матеріалом); засобу «завмирання» - використання кілької повторень у скороченому варіанті;

- варіації (видозмінення мотиву, тобто певних змін використаного раніше хореографічного тексту, яке сприяє цікавому логічному розвитку вцілому та забезпечує необхідні для постійного повторення провідної теми засоби, з метою кращого глядацького сприйняття) та контрасти (залучення істотно нового матеріалу у протиставленні до використаного мотиву, який, за рахунок змін часу, простору, силових характеристик надає хореографічній постановці нового забарвлення), різні елементи композиції, які доповнюють одне одного;

- кульмінації - верхівки хореографічної постановки, підготовленої експозицією, зав’язкою та розвитком дії, до якої, завдяки логічній побудові приводить хореографічний текст (рухи, пози у відповідних ракурсах, міміка, жести і малюнок) та кульмінаційні моменти, досягти яких можна за допомогою використання повторів, акцентів, виділення пауз, контрасту, змін силових і часових характеристик, ритмічної моделі, фокусу руху, зміни динаміки засобами несподіваного акцентування; 
- пропорції та збалансованість частин;

- переходи;

- логічний розвиток та єдність.

Варто зазначити, що тривалий час у хореографічних постановках загалом, i в етюдах зокрема, використовувалася лише одна кульмінація, за якою відповідно йшли розв’язка і фінал, при чому іï побудова відбувалася за рахунок не хореографічних, а драматичних засобів, відповідно до законів драми у певний момент ідея постановника мала отримати вирішення. На сучасному етапі існує тенденція вирішення хореографічного твору за допомогою рухів, без надмірного залучення драматургії, відтак, допускається використання кількох кульмінацій.

Наукова новизна статті полягає в комплексному аналізі композиційних особливостей хореографічного етюду та висвітленні головних принципів композиційної побудови та драматургії постановок.

Висновки. Своєрідність створення хореографічного етюду як невеликого за обсягом, але багатокомпонентного самостійного завершеного сюжетного твору полягає в урахуванні таких компонентів як оранаментальність танцю, що наділяє хореографічну композицію змістовністю та декоративністю, композиція танцю, яка складається зі змісту (драматургіі), відповідного музичного супроводу, хореографічного тексту і малюнка, ракурсів, проте найголовнішим та пріоритетним лишається творча особистість хореографа, його темперамент, уява, образне мислення, цілісність переконань при визначенні надзавдання, сміливість експериментувати задля втілення неординарних, новаторських хореографічних постановок.

\section{Список використаних джерел}

1. Васильєва Е. Танець / Е. Васильєва. - Москва : Мистецтво, 1968. 247 c.

2. Волькенштейн В. Драматургія / В. Волькенштейн. - Москва : Радянський письменник, 1969. - 334 с.

3. Захаров Р. В. Створення танцю : сторінки педагог. досвіду / В. Р. Захаров. - Москва : Мистецтво, 1983. - 224 с.

4. Никитин В. Ю. Композиция в современной хореографии : учеб.-метод. пособие / В. Ю. Никитин, И. К. Шварц ; Моск. гос. ун-т культуры и искусств. Москва : МГУКИ, 2007. - 164 с.

5. Новер Ж. Ж. Письма о танце и балетах / Ж. Ж. Новер. - Ленинград : Искусство, 1965. - 170 с.

6. Трускиновская Д. М. 100 великих мастеров балета / Д. М. Трускиновская. - Москва : Издат. дом «Вече», 2010. - 432 с. 


\section{References}

1. Vasiljeva, T. (1968). Dance. Moscow: Iskusstvo.

2. Wolkenstein, V. (1969). Dramaturgy. Moscow: Radyansky pysmennyk.

3. Zaharov, R. (1983). The creation of dance: pages of teaching experience. Moscow: Iskusstvo.

4. Nikitin, V. (2007). Composition in contemporary choreography. Moscow: Moskovskij gosudarstvennyj universitet kul'tury i iskusstv.

5. Nover, J. (1965). Letters on dancing and ballets. Moscow: Iskusstvo.

6. Truskinovskaja, D. (2010). 100 great ballet masters. Moscow: Publishing house «Veche».

(C) Крись A. I., 2017 